\section{Ks. Zdzisław Żywica}

Uniwersytet Warmińsko-Mazurski, Olsztyn

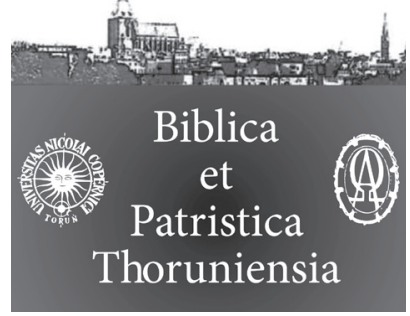

7 (2014) 3 ISSN 1689-5150

DOI: http://dx.doi.org/10.12775/BPTh.2014.015

\title{
Prorok Jeremiasz i Ewangelista Mateusz świadkami wiary zagrożonej anihilacją
}

\section{The prophet Jeremiah and Evangelist Matthew witnesses to the faith threatened by annihilation}

Słowa klucze: Jeremiasz; Mateusz; Izrael; Kościół; wiara; anihilacja.

Keywords: Jeremiah; Matthew; Israel; Church; faith; annihilation.

Streszczenie. Przedstawione powyżej dane i argumenty pozwalają uznać proroka Jeremiasz i ewangelistę Mateusza za wielkich bohaterów broniących wyznawaną, przez nich samych i im współczesnych, wiarę przed totalną anihilacją. Jeremiasz jako wielki bohater wiary Izraela czyni to zapowiadając Nowe Przymierze jakie Bóg zawrze z narodem udającym się do niewoli bez Jerozolimy, świątyni i jej kultu. Zabiera jednak ze sobą Prawo Boże wypisane $w$ ich jestestwach $i$ na sercach, i to ono ocali wiarę na wrogiej obczyźnie i pozwoli ją wskrzesić do życia na nowo, gdy jako Reszta Izraela powróci do zrujnowanej ojczyzny po upływie lat niewoli. Mateusz natomiast ratuje od anihilacji judeochrześcijański Kościół Jezusa i jego wiarę w Jezusa jako Mesjasza i Syna Boga Żywego, podejmując decyzję o opuszczeniu Judei i jej faryzejsko-rabinicznej Synagogi z centralą w Jabne oraz udając się do ludów całej zamieszkałej ziemi z Nowym Przymierzem zawartym we Krwi Jezusa i Jego Ewangelia królestwa, ucząc je zachowywać wszystkiego, co zostało w niej zapisane i przekazane Kościołowi przez Mateusza na wszystkie wieki aż do Paruzji i Sądu Syna Człowieczego (Mt 25,31-46).

Abstract. The abovementioned data and arguments lead to the conclusion that the prophet Jeremiah and evangelist Matthew became great heroes defending faith professed by them and their contemporaries from total annihilation. Jeremiah as a great hero of the faith of Israel does it by announcing New Covenant that God will make with the people travelling to captivity without Jerusalem, the temple and its worship. He takes with him but God's Law written in their hearts and self existance, and that it will save the faith on the enemy's strange land and allow it to resurrect a new life when, as a remnant of Israel, will return to the ruined homeland after years of captivity. Matthew saves from annihilation Judeo-Christian church of Jesus and his faith in Jesus as the Messiah and the Son of the Living God by deciding to leave Judea and her Pharisee-Rabbinic Synagogue headquartered in Jabne and going to the people of the 
whole inhabited Earth with New Covenant made of the Blood of Jesus and His Gospel of the kingdom, teaching them to observe everything that was saved in it and transferred to the Church by Matthew to all the centuries until the Second Coming and Last Judgment of the Son of Man (Mt 25,31-46).

Cy postawienie obok siebie, jako dwóch równych sobie świadków wiary, z jednej strony, niezwykle ważnego proroka dziejów Izraela Jeremiasza, z drugiej zaś, nieznanego z imienia autora pierwszej Ewangelii kanonu Ksiąg Świętych Nowego Testamentu - zwanego Mateuszem, wydaje się zasadne? Czy rzeczywiście obaj byli równymi sobie niezłomnymi obrońcami wiary? By dać na postawione pytania wiarygodną odpowiedź należy spojrzeć na uwarunkowania historyczne i religijno-teologiczne w jakich obaj żyli i działali, rozstrzygnąć czy obaj stanęli przed takim samym wyzwaniem, jakim było ocalenie przed anihilacją wiary wyznawanej przez nich samych i społeczności jakie reprezentowali oraz uważnie przeanalizować czy sam ewangelista Mateusz w jakiś sposób nie kreuje się na Jeremiasza swoich czasów w Jezusowej Ewangelii królestwa jaką zredagował?

\section{Uwarunkowania historyczne ewangelisty Mateusza i judeochrześcijańskiego Kościoła, jaki reprezentuje}

W świetle najnowszych badań należy zasadnie przyjąć, że ostatni redaktor Ewangelii według Mateusza był judeochrześcijaninem palestyńskim doskonale znającym całą tradycję biblijną oraz jej interpretację synagogalną i judeochrześcijańską. Obie interpretacje były ściśle związane z centralnymi ośrodkami judaizmu i judeochrześcijaństwa w Jerozolimie, natomiast po roku 70, jeśli chodzi o judaizm, to z ośrodkiem w Jabne. Ewangelista reprezentuje judeochrześcijaństwo Kościoła jerozolimskiego, w którym musiał żyć i aktywnie działać już od wczesnego okresu popaschalnego, a przez niego również judeochrześcijaństwo palestyńskie rozsiane na terenach Judei, które przez cały czas pozostawało w ścisłej łączności z Kościołem-Matką w Jerozolimie ${ }^{1}$.

Ostatnie lata pobytu kościoła reprezentowanego przez ewangelistę w Judei, szczególnie okres od 66 roku, to czas wręcz śmiertelnego zagrożenia jego dalszej egzystencji. Otwiera go powstanie żydowskie, w wyniku którego wybuchła - z góry skazana na niepowodzenie - wojna z Imperium (66-70/73). Wydaje się, że judeochrześcijanie palestyńscy odmówili czynnego udziału w walce

1 Por. Z. Żywica, Kościót Jezusa, s. 20-21. 363-364. 
zbrojnej przeciwko Rzymowi i z tego powodu gdy chcieli po wojnie wrócić do swych domostw napotykali ze strony Żydów bardzo wiele trudności, między innymi nie mogli ponownie zamieszkać w opuszczonej wcześniej własności, gdyż była już zajęta przez rodaków judaistów. Według Euzebiusza (Hist. Eccl. 3,5,3) wyznawcy Jezusa mieli się przenieść na teren Zajordania - do Pelli, jeszcze przed decydującymi rozstrzygnięciami zbrojnymi, podobnie jak to uczyniła grupa faryzeuszy i uczonych w Piśmie na czele z Johananem ben Zakkai, opuszczając Jerozolimę i udając się do Jabne.

W zniszczeniu Jerozolimy i świątyni judeochrześcijanie widzieli karę za odrzucenie i ukrzyżowanie Jezusa Mesjasza oraz prześladowanie Jego wyznawców. W pismach rabinicznych natomiast porównuje się te wydarzenia z katastrofą roku 587/586, dokonanej przez wojska Nabuchodonozora, rozumianej jako kary za niewierność Przymierzu zawartemu z Bogiem Jahwe. Podobnie jak wówczas, tak i tu ogrom dokonanych zniszczeń zapowiadał nieunikniony zmierzch i całkowite zniknięcie ludu żydowskiego i jego religii z dziejów świata. W pożodze wojennej zniknęły bowiem uchodzące dotąd za fundamentalne dla bytu narodu i jego religii cztery filary: Jerozolima, świątynia i jej kult z liturgią, sanhedryn i urząd arcykapłana wraz z kapłaństwem świątynnym. Położenie mieszkańców Judei po zniszczeniach wojennych przypominało znane już z przeszłości obrazy czasów Ezdrasza i Nehemiasza: utrata suwerenności, zdziesiątkowana ludność, zniewolenie i głębokie zubożenie ocalałej ludności oraz narastająca z czasem coraz głębsza jej zapaść religijna i duchowa. Elity państwowe i religijne wraz z wyższymi warstwami społecznymi zostały uprowadzone do niewoli, w nieznane i niepewne, pozbawione tego wszystkiego co do tej pory stanowiło fundament i sens ich życia religijnego, społecznego i państwowego ${ }^{2}$.

Faryzeusze i uczeni w Piśmie, którzy znaleźli schronienie w Jabne stworzyli tu centralny ośrodek życia i odbudowy struktur społecznych i religijnych ocalałego ludu w oparciu o studium Tory i Tradycji, monopolizując tym samym ich interpretację i wykładnię. Najwybitniejszą postacią pierwszego okresu był bez wątpienia Johanan ben Zakkai (70-80), wykreowany przez jemu współczesnych i następców na zbawcę judaizmu i ludu żydowskiego na wzór biblijnego Ezdrasza. Po nim na czele akademii stanął Gamaliel II - uczeń Hillela i wnuk Gamaliela I (Dz 5,33n). Zasłynął z wypowiedzenia zdecydowanej walki przeciw wszelkim heretykom i schizmatykom, a tym samym jakimkolwiek przejawom heterodoksji wewnątrz odradzającego się judaizmu oraz konsekwentnej i nieugiętej jej realizacji. Jego działalność przypadała na lata 85-95 (Domicjan

2 Por. G. Alon, The Jews, s. 57-76; J. Jocz, Jesus, s. 105-124; J.F. Moore, Judaism; Z. Żywica, Kościót Jezusa, s. 28-30. 
81-96). Wszystko co działo się wewnątrz judaizmu, wiązało się niewątpliwie z dynamicznie rozwijającym się i coraz bardziej wyraźnie określonym doktrynalnie i instytucjonalnie judeochrześcijaństwem, które przyjmując Septuagintę za własny kanon ksiąg świętych poddawało je interpretacji chrystologicznej, co otworzyło drogę ostrym dyskusjom i polemikom w kwestii tak fundamentalnej, jak odpowiedź na pytanie: kto jest teraz i pozostanie w przyszłości $V e$ rus Israel - Prawdziwym Izraelem? Trzeba było zatem zająć stanowisko wobec problemu kanoniczności i natchnienia ksiąg Biblii Hebrajskiej i jej greckiego przekładu Septuaginty. W wyniku długich i burzliwych apologetyczno-polemicznych dyskusji rabini podzielili dostępne im księgi na cztery kategorie: natchnione księgi biblijne, księgi nie-natchnione (np. Ben Syrach), teksty do czytania, ale nie do studium (np. Homer) i księgi heretyckie - zwane $s^{e} f a r i m$ hizonim. Bez wątpienia to również judeochrześcijaństwo przyczyniło się do pogłębienia $\mathrm{w}$ odradzającym się judaizmie rozróżnienia i podziału między Torą spisaną a Tradycją - Torą ustną i to z tego względu, że także całe chrześcijaństwo rościło sobie prawo do autentycznego dziedzictwa Tory spisanej i pozostałych świętych Pism biblijnego Izraela. Reformatorzy jabneńscy starali się położyć zdecydowanie większy akcent na to, co pozostawało nadal jedynie ich własnością i dziedzictwem po przodkach, a mianowicie na Torę ustną. Byli przekonani, że sam Jahwe zawarł swą odpowiedź na pytanie o Verus Israel nie gdzie indziej, jak tylko w Torze ustnej, stąd też każdy, kto jej nie zna, nie może należeć do Prawdziwego Izraela. Tak radykalne rozstrzygnięcie rodziło negatywne postawy w stosunku do rodzącej się tradycji judeochrześcijańskiej i utrwalających ją w piśmie ksiąg (Ewangelie i inne pisma), określane przez rabinów jako gilyonim oraz sifre minim, tzn. takie, które nie brudzą rąk, zatem nie są natchnione (Yadaim II,13; bShab. 116a; pShab. 16,15c). Dla rabinów nawet tylko przepisana przez heretyków (m.in. chrześcijan) Tora i pozostałe Pisma, choć uznane przez nich samych za „brudzące ręce”, są przez to pozbawione świętości ${ }^{3}$.

Zmiany w liturgii, w której uczestniczyli również judeochrześcijanie i sympatycy "nowej drogi”, dotyczyły głównie tych obszarów, gdzie dyskusji poddawano prawdy wiary, a więc tam, gdzie dotykano prawdy o jedyności Boga oraz kwestii boskiej natury Mesjasza. Stąd też wprowadzane zmiany wymierzone zostały przeciwko heterodoksji, a głównie przeciwko judeochrześcijaństwu. Najbardziej znaczące zmiany dotyczyły modlitwy shema i amida. W samej treści modlitwy shema nie dokonano zmian, jednak odtąd stała się dla każdego

3 Por. J. Neusner, Das Pharisäische, s. 25-95; idem, Judentum; idem, The Formation, s. 3-42; idem, The Rabbinic; G. Stemberger, Die sogenannte, s. 14-21; Z. Żywica, Kościót Jezusa, s. 22-25. 
Żyda fundamentalnym aktem wyznania wiary w jedyność Boga Jahwe. To niebywałe wyeksponowanie shema wyraźnie świadczy o intensywności polemiki sięgającej samej istoty doktryny wiary, a tym samym o ostrym konflikcie z judeochrześcijaństwem, które zdaniem rabinów z Jabne było najgorszą ze wszystkich herezją i idolatrią. Modlitwa amida - shemone 'ezre, czyli osiemnastu błogosławieństw (faktycznie 19) została wydana po raz pierwszy w wersji urzędowej i jedynie obowiązującej za czasów Gamaliela II (85-95). Wtedy też ustalono częstotliwość i sposób jej odmawiania. Werset brzmiący: „Błogosławione Jego imię, którego chwalebne Królestwo jest na zawsze” miał być odtąd odmawiany po cichu ze względu na minim, by ich zidentyfikować. Szczególnie istotną i brzemienną w skutki dla judeochrześcijan miała treść wprowadzona w tym czasie do dwunastego błogosławieństwa znanego jako birkat ha-minim: „A potwarcy niech nie mają nadziei, a wszyscy sprawcy niegodziwości w oka mgnieniu niech zginą i wszyscy niech rychło będą wytraceni, a zbrodniarzy rychło wykorzeń i skrusz i zniszcz i upokórz rychło za dni naszych. Pochwalonyś Ty, Wiekuisty, który kruszysz wrogów i upokarzasz zbrodniarzy"4. W toczącej się nadal dyskusji na temat kogo należy rozumieć przez minim i nocerim, liczni uczeni przyjmują, że bez wątpienia trzeba w nich widzieć judeochrześcijan, obok wszelkiej denominacji heretyckich grup judaizmu oraz władz rzymskich i ich żydowskich kolaborantów. W ich przekonaniu birkat ha-minim może uchodzić za akt definitywnego rozłamu i rozejścia się dróg judeochrześcijańskiego Kościoła Jezusa z Nazaretu w Galilei i faryzejsko-rabinicznej Synagogi w Judei. Rabini znacznie surowiej traktowali minim niż pogan. Podejrzenie o herezję chrześcijaństwa lub tylko jej sprzyjanie było aż nadto wystarczającym powodem do wykluczenia ze społeczności żydowskiej, bowiem judeochrześcijaństwo uważano za herezję najbardziej zagrażającą integralności judaizmu poświątynnego. Konsekwencje takiej praktyki były niezwykle bolesne dla wyznawców Jezusa, gdyż dotkniętemu ekskomuniką min/nocer - judeochrześcijaninowi nie wolno było nic sprzedawać ani od niego kupować, czy też korzystać z jego usług. Ich dzieci nie wolno było uczyć zawodu. Wyznawcy judaizmu mieli uważać jego samego i rodzinę za renegatów i wyrzutków, którym w żadnych okolicznościach nie wolno pomagać, lecz raczej ich życie wystawić na niebezpieczeństwo (Str.Bill. IV, 33n). Ksiąg należących do minim/nocerim nie wolno było ratować z ognia, nawet jeżeli zwierają słowo Boże. Mięso od nich musiało być traktowane jak ofiarowane bóstwom (idolatria), a ich chleb jak chleb Samarytan (Str.Bill. III, 11). Wino należało traktować jako przeznaczone dla idoli (pShab. 13,5; bShab. 116), ich księgi jako księgi czarownic, a dzieci jako bękarty - mamzerim (T. Hullin 2, 20-24). Dając praktyczne wskazówki,

4 S. Spitzer, Modty Izraelitów, s. 109.111. 
w jaki sposób można rozpoznać minim/nocerim, rabini twierdzili, że judeochrześcijan najłatwiej rozpoznać podczas liturgii synagogalnej po zachowaniu i recytacji modlitwy amida (Megillah IV, 8) ${ }^{5}$.

W takich oto uwarunkowaniach, przypominających mu zapewne żywo czasy Jeremiasza, przyszło Mateuszowi podjąć pracę nad ostatecznym kształtem greckiej wersji Ewangelii i kontynuować to dzieło jeszcze po opuszczeniu Judei, już na terenie Galilei, gdzie przez pewien czas przebywał wraz z wybranymi $(24,22.29-31 ; 26,32 ; 28,16-20)$ i ocalonymi z pożogi wojennej, prześladowań i wewnętrznego upadku w wierze i moralności członkami własnej i innych wspólnot palestyńskich doświadczonych podobnym losem i opuszczających swe dotychczasowe miejsce pobytu i działalności misyjnej. Pracę nad nią zakończył zapewne dopiero w pierwszych latach pobytu w Syrii, najprawdopodobniej w Antiochii, początkowo zapewne wśród diaspory judeochrześcijańskiej, co mogło przypadać na lata 90-95, czyli we wstępnej fazie otwierania się i jednoczenia z Kościołem Powszechnym, w znacznej mierze etnochrześcijańskim $^{6}$.

\section{Racje teologiczne wypracowane przez ewangelistę Mateusza i palestyński Kościół judeochrześcijański}

Pełną grozy sytuację anihilacji, w jakiej znalazł się reprezentowany przez Mateusza palestyński Kościół judeochrześcijański szczególnie po roku 70, ewangelista oddaje w zredagowanej przez siebie Ewangelii, u której podstaw położył fundamentalne, dla dalszej egzystencji fizycznej i doktrynalnej Kościoła, racje teologiczne.

Ewangelista doskonale znał przekonania reformatorów z Jabne, że to sam Jahwe zawarł swą odpowiedź na pytanie o Verus Israel w Torze ustnej, którą to odtąd wyłącznie oni dziedziczą i aktualizują. W odpowiedzi na tak radykalne rozstrzygniecie Mateusz dokonuje judeochrześcijańskiej reinterpretacji Pism Izraela i wskazuje na Kościół Jezusa jak na Verus Israel, reprezentowany odtąd przez Wielki Kościół Chrześcijański, złożony z judeo- i etnochrześcijan w całym świecie, do którego się właśnie udaje opuszczając Judeę. Reinterpretacja ta szczególnie widoczna jest w licznych cytowaniach tekstów biblijnych, rozmieszczonych w całej Ewangelii - poprzedzanych tzw. formułami wprowadzającymi. Służą mu one wskazywaniu na dokonywaną reinterpretację całej

5 Por. E. Schürer, G. Vermes, The History 7; S. Zeitlin, Beginnings of Christianity, s. 385-398; S. Zeitlin, The Rise; Z. Żywica, Kościół Jezusa, s. 26-28.

6 Por. Z. Żywica, Kościół Jezusa, s. 363-364. 
tradycji biblijnej w świetle osoby i zbawczego dzieła Jezusa z Nazaretu, który w jej świetle jednoznacznie jawi się jako Mesjasz i Syn Boga Żywego. Widać to równie wyraźnie w reinterpretacji Tory w Kazaniu na Górze - wprowadzanej formułami: słyszeliście, że powiedziano ..., a ja wam powiadam... (Mt 5,21-48) oraz $\mathrm{w}$ nadaniu prawdziwego sensu pobożności judaistycznej opierającej się na trzech filarach: jałmużnie, modlitwie i poście (Mt 6,1-18); tu wskazuje na prawdziwego jej ducha, krytykując egocentryzm, pychę i hipokryzję dotąd ją praktykujących. We wzmiance o wstąpieniu Jezusa na Górę w celu wygłoszenia pierwszej mowy (Mt 5-7) oraz w samej konstrukcji struktury całej Ewangelii wyraźnie odwołuje się do osoby Mojżesza i Tory. Pięć mów poprzedzonych materiałem narracyjnym daje pięć wyraźnie wydzielonych części, co niewątpliwie nawiązuje do Pięcioksięgu. Dołączając jeszcze kolejne dwie: na początku historię dzieciństwa (Mt 1-2) i na końcu historię paschalną Jezusa (Mt 26-28) tworzy Siedmioksiag. Uwzględniając symbolikę liczby siedem (pełnia, doskonałość) ewangelista ukazuje Ewangelię Jezusa Nazarejczyka - Mesjasza i Syna Boga Żywego jako nową Doskonała Tore, a siebie prezentuje jako tego uczonego w Piśmie, który zgodnie $\mathrm{z}$ wolą samego Jahwe stał się uczniem Jezusowego królestwa. Z prawdziwie Bożą mądrością, charakteryzującą wcześniej proroków, wydobywa on ze skarbca tradycji biblijnej Izraela i Nauki Jezusa rzeczy stare i nowe (Mt 13,52), rozstrzygając ostatecznie kto z woli Jahwe jest odtąd Prawdziwym Izraelem.

Mateusz podobnie też widzi i ocenia sytuację Judei i jej Kościoła judeochrześcijańskiego po wojnie żydowskiej, jak reformatorzy z Jabne sytuację i stan narodu żydowskiego oraz jego religii; porównują te wydarzenia do katastrofy roku 587/586 przed Chr. W swojej Nowej Torze, tj. Ewangelii królestwa, nawiązuje do ówczesnej sytuacji, szczególnie w trzykrotnym przywołaniu wprost osoby proroka Jeremiasza $(2,17 ; 16,14 ; 27,9)$ i dwukrotnym cytowaniu tekstów z Księgi noszącej jego imię (Mt 2,16-18; Jr 31,15; Mt 27,9 aluzja do Za 11,12n; Jr 18,1-12; 19,1-13).

Po raz pierwszy czyni to zaraz na początku redagowanej Ewangelii, po opisie rzezi niemowląt w Betlejem. Czytamy tam, że w lamencie rodziców matek z Betlejem wypełniają się słowa proroka Jeremiasza: Krzyk usłyszano w Rama, płacz i lament wielki. Rachel opłakuje swe dzieci i nie chce utulić się $w \dot{z} a l u$, bo ich już nie ma (Mt 2,18; Jr 31,15). Według proroka Jeremiasza Rachel - Matka Izraela, gorzko opłakuje los narodu Izraela po klęsce zadanej przez wojska Nabuchodonozora.

Mateusz poprzedza ów cytat opowiadaniem o magach przybyłych do Heroda i ucieczce św. Rodziny do Egiptu. Wydaje się, że odwołaniem do Egiptu (Mt 2,13-15), ewangelista jeszcze bardziej intensyfikuje wyrażony płaczem Racheli stan zagrożenia fizycznej eksterminacji nie tylko Dziecięcia Jezus, lecz 
również judeochrześcijańskiego Kościoła jego czasów, czego sugestię należy dostrzec w zachowaniu całej Jerozolimy wraz z Herodem na wieść o nowo narodzonym Królu żydowskim: Skoro to ustyszał król Herod, przeraził się, a $z$ nim cała Jerozolima (Mt 2,3). Na poziomie historycznym trudno założyć by cała Jerozolima już wówczas wiedziała o nowo narodzonym królu i zachowała się identycznie jak Herod. Wydaję się, że reakcją całej Jerozolimy ewangelista wskazuje na późniejsze wydarzenia: Tydzień Paschalny Jezusa, pierwsze prześladowania Kościoła jerozolimskiego skutkujące zabójstwem Szczepana, Jakuba Starszego i Jakuba Młodszego oraz nasilające się prześladowania judeochrześcijan i wykluczenia ich z Synagog po wojnie żydowskiej, prowadzące ostatecznie do definitywnego, wrogiego rozejścia się dróg Kościoła i reformowanej w Jabne Synagogi. Według Mateusza zatem Rachel nie tylko opłakiwała los Jerozolimy i ludu Izraela zmierzającego do niewoli babilońskiej, ale teraz opłakuje również los dzieci betlejemskich i ich matek oraz los Kościoła palestyńskiego czasów ewangelisty. Judeochrześcijanin Mateusz udowadnia tu, że doskonale widzi i opisuje jedność dziejów zbawienia, definitywnie już wypełniających się w osobie i dziele Jezus z Nazaretu. Przedstawia tę jedność bynajmniej nie w gorszym stylu niż faryzeusze swoją interpretację dziejów zbawienia w akademii jabneńskiej?

Po raz drugi osobę proroka Jeremiasza ewangelista przywołuje $\mathrm{w}$ opisie wydarzenia zwanego często „wyznaniem wiary w Cezarei” (Mt 16,13-20; por. Mk 8,27-30; Łk 9,18-21). Na pierwsze pytanie Jezusa: „Za kogo ludzie uważają Syna Człowieczego?”, Piotr odpowiada: „Jedni za Jana Chrzciciela, inni za Eliasza, jeszcze inni za Jeremiasza albo za jednego z proroków" (Mt 16,13n). Interesujący jest brak wzmianki o Jeremiaszu w redakcjach Marka i Łukasza. Na drugie pytanie Jezusa: „A wy za kogo mnie uważacie?”, odpowiada: „Ty jesteś Mesjasza, Syn Boga Żywego" (Mt 16,15n). Perykopa ta zajmuje niezwykle istotne miejsce $\mathrm{w}$ Ewangeliach, gdyż wyznacza ona moment przełomowy w życiu i misji Jezusa. Zaraz po wyznaniu słyszymy Jezusa, „że musi iść do Jerozolimy i wiele cierpieć od starszych i arcykapłanów, i uczonych w Piśmie; że będzie zabity, a trzeciego dnia zmartwychwstanie" (Mt 16,21 par.). Tylko Mateusz szeroko rozwija całe to wydarzenie, dodając słowa Jezusa o zbudowaniu Kościoła na Piotrze jako Opoce (Mt 16,17-20). Przywołaniem osoby proroka Jeremiasza Mateusz wraca do pierwszej o nim wzmianki w Ewangelii Dzieciństwa i przywołuje tym samym na pamięć wydarzenia związane z osobą historycznego Jeremiasza oraz Dziecięcia Jezus. Wyraźnie zleży mu na kontynuacji tego wątku w kluczowym miejscu Ewangelii, w chwili w której Jezus zapowiada swój tragiczny los jaki dopełni w Jerozolimie. Z perspektywy lat już wie, że po-

7 Por. A. Paciorek, Ewangelia, s. 122-124. 
dobny los spotkał Apostołów (por. Mt 16,24 par.) jak również doświadczył go on sam i judeochrześcijański Kościół jaki reprezentuje, o czym szeroko pisze w rozdziale $24^{8}$.

Lament Racheli w księdze Jeremiasza umiejscowiony jest w kontekście pełnym nadziei. Rozdziały Jr 30 - 31 stanowią Księgę Pocieszenia obejmującą zapowiedź odbudowy na fundamencie Nowego Przymierza: „Oto nachodzą dni - wyrocznia Pana - kiedy zawrę z domem Izraela «i z domem judzkim» nowe przymierze. Nie jak przymierze, które zawarłem $z$ ich przodkiami, kiedy ująłem ich za rękę, by wyprowadzić $\mathrm{z}$ ziemi egipskiej. To moje przymierze złamali, mimo że byłem ich Władcą - wyrocznia Pana. Lecz takie będzie przymierze, jakie zawrę $z$ domem Izraela po tych dniach - wyrocznia Pana: Umieszczę swe prawo w głębi ich jestestwa i wypiszę na ich sercu. Będę im Bogiem, oni zaś będą Mi narodem. I nie będą się musieli wzajemnie pouczać jeden mówiąc do drugiego: «Poznajcie Pana!» Wszyscy bowiem od najmniejszego do największego poznają Mnie - wyrocznia Pana, ponieważ odpuszczę im występki, a o grzechach ich nie będę już wspominał" (31,31-34). Jeremiasz zapowiada, że dzięki łaskawemu działaniu Boga lud Izraela ocali swą wiarę. Powróci on do Boga i stanie się ponownie Jego ludem nie dzięki własnej postawie i działaniom, lecz dzięki temu, że to najpierw On sam powróci do nich i stanie się ich Bogiem w momencie wpisania w głębię ich jestestwa i na ich sercach Prawa, które wcześniej odrzucili, łamiąc zawarte z Nim Przymierze.

Ewangelista Mateusz, podobnie jak Jeremiasz, również mówi o budowie i Nowym Przymierzu we Krwi Jezusa. Zapowiada to Jezus w wypowiedzi skierowanej do Piotra: „Zbuduję Kościół mój”. Jego Kościół zbudowany na Piotrze - Opoce nie dozna zniszczenia: „a bramy piekielne go nie przemogą” (Mt 16,18-20). Gwarantem trwałości Kościoła będzie On sam jak zmartwychwstały Pan, przebywając w nim przez wszystkie dni aż do skończenia świata, o czym zapewnił swoich Jedenastu Apostołów na Górze w Galilei (Mt 28,20). Wyraźnie widać, że Mateusz ukazuje tu siebie jako nowego Jeremiasza, wielkiego bohatera wiary i narodu Izraela. Dla Jeremiasza gwarantem przetrwania wiary w Reszcie Izraela był sam Bóg Jahwe, który umieścił swe Prawo w głębi jej jestestwa i wypisat je na ich sercach. Dla Reszty Izraela i dla tych do których ona powróciła na terenie Judei ponownie stał się Bogiem, oni zaś dla Niego Jego narodem. Dla Mateusza gwarantem ocalenia wiary w Jezusa Mesjasza i Syna Bożego będzie On sam jako zmartwychwstały Pan - Emmanuel, na za-

8 Por. I. Broer, Redaktiongeschichtliche Aspekte, s. 209-233; S. Légasse, Le refroidisment, s. 91-102; C. Spicq, Lamour de charité, s. 113-117; J. Taylor, The Love of Many, s. 352-357; W.G. Thompson, A Historical Perspective, s. 243-262; Z. Żywica, Kościół Jezusa, s. $238-246$. 
wsze obecny w zbudowanym przez siebie Kościele na fundamencie Nowego Przymierza zawartego we Krwi Jezusa oraz pisemnym świadectwem zawartego Przymierza, tj. Ewangelia królestwa ogłoszoną przez Jezusa w Izraelu, a teraz spisywaną w ostatecznym swym kształcie dla Kościoła zmierzającego ku nowym wyzwaniom w obcy dla siebie świat. Zdumiewa tu formuła wypowiedziana przez Piotra do Jezusa: „Ty jesteś Mesjasz, Syn Boga Żywego”. Podczas gdy u Marka brzmi ona: „Ty jesteś Mesjasz” (Mk 8,29), a u Łukasza: „Za Mesjasza Bożego" (Łk 9,20). Mateusz nadaje temu wyznaniu wiary pełnię?. Zamyka w nim wiarę chrześcijańską doprowadzoną do swej dojrzałości. Uwzględnia ono prawdziwą wolę Bożą zawartą w całej tradycji biblijnej Izraela i Nauce Jezusa. Ewangelista buduje w ten sposób geder - płot, swego rodzaju obronny „system immunologiczny” przed błędnymi wpływami religii pogańskich i ich rozumienia Boga. Czyni to podobnie jak reformatorzy w Jabne, którzy Tradycję Ustną uznali za geder przed wszelkiego rodzaju heterodoksją, szczególnie zaś wiarą judeochrześcijańską. Mateusz podobnie jak Jeremiasz podejmuje walkę o czystość wiary; Jeremiasz przed politeizmem babilońskim, Mateusz zaś przed politeizmem grecko-rzymskim.

Po raz trzeci ewangelista przywołuje wprost osobę Jeremiasza w opowiadaniu o podjętych przez Judasza działaniach (Mt 27,3-10) po wydaniu Jezusa Piłatowi przez arcykapłanów i starszych ludu (Mt 27,1-2). Na zakończenie opisu cytuje tekst biblijny, który przypisuje prorokowi Jeremiaszowi: „Wzięli trzydzieści srebrników, zapłatę za Tego, którego oszacowali synowie Izraela. I dali je za Pole Garncarza, jak mi Pana nakazał" (Mt 27,9n). Jest to tekst mieszany odwołujący się do Zch 11,4-17 (o trzydziestu srebrnikach) oraz Jr 18,1-12 (alegoria o garncarzu i naczyniach) i Jr 19,1-13 (o stłuczeniu naczynia garncarskiego i grzebaniu zmarłych w Tofet) ${ }^{10}$.

9 Por. J. Guillet, Jezus w wierze, s. 145-149.

10 Omawiana perykopa posiada liczne związki z tekstami biblijnymi. Judasz (w. 3) wspomniany jest w Za 11,14; Jr 18,11; 19,3.7.13; 32,11-14 („Juda”). Trzydzieści srebrników (w. 3) wymienione zostały w Za 11,12-13. Wyżsi kapłani i starsi (w. 3) są przywołani także w Jr 19,1 („starsi ludu i starsi kapłani”). Porzucenie srebrników w świątyni (w. 5) nawiązuje do Za 11,13 (i wziąłem trzydzieści srebrników i wrzuciłem je do domu Pana”). Odejście Judasza i powieszenie (w. 5) przywołuje na pamięć Achitofela z 2Sm 17,23 („który poszedł i powiesił się"). Kupienie pola garncarza (w. 7) przypomina alegorię garncarza z Jr 18,1-12. W Jr 19,1 znajduje się polecenie dane prorokowi, aby rozbił gliniany dzban. Jr 32,6-15 opowiada o zamiarze zakupienia ziemi przez proroka. Wzmianka o grzebaniu cudzoziemców (w. 7) nawiązuje do Jr 19,11, gdzie mowa o grzebaniu umarłych w Tofel. Fraza wzięli trzydzieści srebrników (w. 9) przypomina dokładnie Za 11,13; I dali na pole garncarza (w. 10) przypomina Jr 32,6-15, gdzie mowa o zakupieniu pola przez proroka. Wzmianka o garncarzu ponadto w Za 11,13 i Jr 18,1-12. Por. W.D. Davies, D.C. Allison, The Gospel, s. 570. 
W przypadku Zch 11,4-17 wydaje się, że Mateusz reprezentuje tu znaną mu tradycję, lub też wyraża własne przekonanie, iż tekst ten $11,4-17$ jest autorstwa proroka Jeremiasza. Jest to wysoce prawdopodobne, jeśli uwzględnimy, że rozdziały Zch 9-14, obejmujące szereg napomnień, gróźb i obietnic uchodziły za anonimowe, nieznanego pochodzenia jeden lub więcej autorów, zostały dołączone do Księgi Zachariasza z przypisaniem ich Zachariaszowi synowi Berekiasza, podczas gdy rozdziały 1-8 przypisywane są Zachariaszowi synowi Iddo, prorokowi współczesnemu Aggeuszowi ${ }^{11}$. Mateusz cytuje tu tekst odnoszący się do trzydziestu srebrników, które odliczono dla proroka i dla Judasza. Z kontekstu zaś dowiadujemy się, że zostały one porzucone w świątyni zarówno przez proroka jak i przez Judasza ${ }^{12}$. Równie ważne jak srebrniki są dla ewangelisty w tym tekście również metafory o złamaniu dwóch lasek. Złamanie pierwszej, zwanej Łaskawość miała symbolizować zerwanie przez Boga przymierza zawartego $z$ wszystkimi ludami (Zch 11,10). Uwzględniając kontekst historyczny i teologiczny Mateusza i jego Kościoła, można założyć, że ewangelista widzi tu zerwanie dotychczas obowiązującego przymierza, zawartego między Bogiem i Izraelem a narodami pogańskimi, a mianowicie, że to Izrael doprowadzi je do poznania i uwielbienia jedynego prawdziwego Boga. Nie zostało ono zrealizowane z powodu niewierności Izraela i dlatego Bóg zawarł Nowe Przymierze we Krwi Jezusa, przelanej za wielu na odpuszczenie grzechów (Mt 26,26-30). Teraz to Kościół Jezusa udający się do świata pogan będzie tradendem tego Nowego Przymierza ${ }^{13}$. Taki tok rozumowania wydaje się potwierdzać złamanie drugiej laski, zwanej Zjednoczenie, co miało symbolizować zerwanie braterstwa Judy z Izraelem. Dla Mateusza nie może to oznaczać niczego innego jak dokonujące się na jego oczach niezwykle bolesne zerwanie braterstwa między Judeą i pozostającą na jej terytorium Synagogą jabneńską, a judeochrześcijańskim Kościołem - Prawdziwym Izraelem z którym opuszcza Judeę.

11 Por. R.J. Coggins, Haggai, Zechariah, s. 61-71.

12 Opowiadanie o dwóch pasterzach porusza problematykę podobną do tej z opowiadania o złych pasterzach z Jr 23,1-8, gdzie znajduje się zapowiedź mesjańska o wzbudzeniu Dawidowi Odrośli sprawiedliwej, który jako król będzie postępowat sprawiedliwie $i$ wykonywat prawo i sprawiedliwość (Jr 23,5n). Nie ulega wątpliwości, że dla Mateusza zapowiedź ta w pełni zrealizowała się w osobie i dziele Jezusa z Nazaretu.

13 O możliwości zerwania owego Przymierza mówi Jan Chrzciciel do przybyłych do niego reprezentantów religijnych elit żydowskich: „Plemię żmijowe, kto wam pokazał, jak uciec przed nadchodzącym gniewem? Wydajcie więc godny owoc nawrócenia, a nie myślcie, że możecie mówić: "Abrahama mamy za ojca», bo powiadam wam, że z tych oto kamieni może Bóg wzbudzić dzieci Abrahamowi. Już siekiera do korzenia drzew jest przyłożona. Każde więc drzewo, które nie wydaje dobrego owocu, będzie wycięte i w ogień wrzucone" (Mt 3,7-11). 
Drugi tekst z Jr 18,1-12 to alegoria o garncarzu i wykonywanych przez niego naczyniach. Mateusz widzi wypełnienie słów Boga wypowiedzianych za pośrednictwem Jeremiasza w wydarzeniach których on i jego Kościół jest świadkiem. Jeremiasz słyszy słowa Pana: „Teraz zaś mów mężom judzkim i mieszkańcom Jerozolimy: To mówi Pan: Oto przygotuję dla was nieszczęście i snuję przeciw wam plan. Nawróćcie się więc każdy ze swej złej drogi, a uczyńcie lepszym wasze drogi i wasze czyny! I rzekli oni: Na próżno! Chcemy raczej pójść za swoimi własnymi przekonaniami; każdy będzie postępowat według popędu swego przewrotnego serca" (Jr 18,11n; por. 19,1-13). Bóg wzywał do nawrócenia Judę i Jerozolimę w swoim Synu Jezusie z Nazaretu, ci jednak nie posłuchali Go, odrzucili Jego samego i Kościół który tam zbudował. Wówczas zesłał na nich zapowiadane nieszczęście w postaci zniszczenia Jerozolimy, jej świątyni i kultu. Ci jednak i wówczas nie posłuchali swego Boga, lecz postąpili wedtug popędu swego przewrotnego serca, czego wyrazem jest odbudowa i reforma judaizmu podjęta w Jabne jako kontrofensywa wymierzona w Kościół Jezusa. Przewrotność serca elit ówczesnego judaizmu faryzejsko-rabinicznego ewangelista w niezwykle dobitny i jaskrawy sposób przedstawia w rozdziale 23 swej Ewangelii.

Podobny sens wyraża Jr 19,1-13, gdzie jest mowa o stłuczeniu naczynia garncarskiego i grzebaniu zmarłych w Tofet. Prorok ma przekazać starszym ludu i starszym kapłanom następujące słowa Pana: „Tak samo zniszczę ten naród i to miasto, jak tlucze się naczynie garncarskie, którego nie można już naprawić... Domy Jerozolimy i domy królów judzkich stana się nieczyste, podobnie jak miejsce Tofet..." (Jr 19,11-13). Naczynie garncarskie którego nie można już skleić, dla Mateusza, to zapewne odbudowywany w Jabne judaizm, który nie da się już skutecznie posklejać, zreformować. Jest to absolutnie niemożliwe, ponieważ utracił on nieodwracalnie skuteczność zbawczą. Bóg opuścił Jerozolimę i jej świątynię. „Oto wasz dom zostaje wam pusty” (Mt 23,38), ogłasza Jezus Emmanuel religijnym elitom judaizmu na terenie świątyni i pozostanie taki aż do w chwili w której wyznają wiarę w Niego jako Mesjasza i Syna Jahwe: „Albowiem powiadam wam: Nie ujrzycie Mnie odtąd, aż powiecie: Błogosławiony, który przychodzi w imię Pańskie" (Mt 23,39). Jako Emmanuel opuszcza ruiny Jerozolimy i świątyni wraz z Kościołem i udaje się do świata pogan by tam głosić i urzeczywistniać Nowe Przymierze jakie Bóg zawarł między Prawdziwym Izraelem - Kościołem Jezusa, a ludami całej zamieszkałej ziemi. Będzie wypełniać polecenie wypowiedziane przez zmartwychwstałego Jezusa do Jedenastu Apostołów na górze w Galilei: „Idźcie więc i nauczajcie wszystkie narody, udzielając im chrztu w imię Ojca i Syna i Ducha Świętego. Uczcie je zachowywać wszystko, co wam przykazałem. A oto Ja jestem z wami przez wszystkie dni aż do skończenia świata" Mt 28,19n). 
Podobnie jak Jeremiasz, za wszystkie nieszczęścia jakie spadły na Izraela z rąk wojsk Nabuchodonozora, tak również Mateusz jest całkowicie przekonany o pełnej winie religijnych elit Izraela za śmierć Jezusa i prześladowania Jego Kościoła. To przekonanie z niezwykłą ekspresją ukazuje w scenie przedstawiającej ostatni akt historii Judasza. Według Mateusza Judasz pełnił funkcję jedynie instrumentu $\mathrm{w}$ realizacji zbrodniczego planu przygotowywanego przez przywódców ludu $(12,14 ; 26,3-5.14-16)$, co sami tak cynicznie okazali mu w czasie ich ostatniego spotkania: „Co to nas obchodzi? To twoja sprawa” $(27,4 b)^{14}$. Dla nich Jezus, nawet jako zupełnie niewinny człowiek, musiał umrzeć. Mateusz, pisząc o wewnętrznych przeżyciach Judasza, zaznacza, że $g d y$ odczuł żal, ostatecznie zwrócił arcykapłanom i starszym trzydzieści srebrników (27,4a; por. 21,29.32). Zrozumiał niegodziwość swego czynu i wie, że zgrzeszyt, wydajac krew niewinna ${ }^{15}$. Arcykapłani i starsi ludu utwierdzili w nim przekonanie, że dopuścił się niezwykle ciężkiego przestępstwa zabronionego w Torze, dlatego też uznał siebie za przeklętego przez Boga, co w konsekwencji spowodowało, że sam na siebie wydał wyrok śmierci i wykonał go zgodnie z Pwt $21,22{ }^{16}$. Dla Mateusza taka śmierć Judasza pokazuje, że Tora w jabneńskiej interpretacji nie prowadzi już do życia, lecz wręcz przeciwnie, do śmierci. Tym który daje odtąd życie, wyzwalając duszę ludzką z więzów śmierci, jest Jezus na drodze wypełniania Jego Ewangelii królestwa.

W następnych wersetach odsłania fałszywe świadectwo i hipokryzję religijnych elit $(27,6)^{17}$. Ci sami ludzie, którzy przedtem wydali wyrok śmierci na niewinnego człowieka, teraz gorliwie zajmują się drobiazgową interpretacją Prawa, co jest nieporównywalnie nieistotne i błahe wobec czynu, jakiego sami się dopuszczają: nie okazali aktu współczucia, a nawet typowego dla ich postawy - nieszczerego zrozumienia dla współdziałającego w złu Judasza. Dostrzegli też, że srebrniki, które im zwrócił sa oszacowaniem krwi $(27,6)^{18}$. Z kompromitującej ich sytuacji szybko znajdują bezpieczne dla siebie wyjście, kupują za nie Pole Garncarza na grób cudzoziemcom (27,7); przestępstwo przeciwko Torze usprawiedliwiają samą Torą. W komentarzu z 27,8 („Dlatego pole to, aż po dziś dzień, nosi nazwę Pole Krwi”) Mateusz po raz pierwszy w Ewangelii tak wyraź-

14 Identycznie postąpi Piłat wobec oskarżającego Jezusa tłum, podburzonego przez arcykapłanów i starszych ludu $(27,20.24)$.

15 Por. W.D. Davies, D.C. Allison, The Gospel, s. 563.

16 Według Mateusza na taką karę zasługiwali jedynie przywódcy ludu, a wiedząc o tym, właśnie taką postawę przyjęli wobec Judasza. Por. D. Daube, Judas, s. 95-108; C.E. Wehelan, Suicide, s. 505-522.

17 Por. Pwt 23,19.

18 Por. U. Luz, Das Evangelium, s. 239. 
nie nawiązuje do czasu mu obecnego, eksponując w ten sposób kontynuowany, w historii paschalnej, temat jedności, zakorzenienia historii Jezusa z Nazaretu w historii jego Kościoła, w którym obecny jest cały czas ten sam Jezus jako Emmanuel. Cytowany tekst biblijny Mateusz wprowadza po raz ostatni w Ewangelii uroczystą formułą wypełnienia (27,9n). Formuła wprowadzająca jest identyczna $\mathrm{z}$ tą $\mathrm{w} 2,17$, przez co ewangelista tworzy tu szeroką inkluzję $2,17-27,9 \mathrm{n}$, obejmującą historię Jezusa od samego narodzenia ${ }^{19}$. Tworząc inkluzję z 2,17, przy uwzględnieniu faktu tak bezpośredniego odniesienia się przez niego do jego własnej teraźniejszości w 27,8, niewątpliwie chce on po raz kolejny podkreślić, w typowy dla siebie sposób, że śmiercionośne zło, jakiego doświadczył Jezus i Jego Kościół w Izraelu, pochodziło nie od kogo innego, jak tylko od synów Izraela, myśląc tu o jego religijnych elitach, ponieważ inni bezpośrednio związani z nimi i występujący dotychczas (Judasz oraz tłum z mieczami i kijami), pełnili jedynie funkcję narzędzi w ich rękach. Ewangelista w najwyższym stopniu swych narracyjnych umiejętności podkreśla jeszcze raz, w kontekście historii Judasza, żałującego zdrady swego Nauczyciela, ich złą wolę, wrogość i nienawiść tuż przed procesem u namiestnika Piłata, w czasie którego zostanie jeszcze dwukrotnie dobitnie ukazana absolutna niewinność osoby Jezusa, raz przez żonę Piłata $(27,19)$, a drugi raz przez samego Piłata $(27,4)$, winę zaś za przelanie niewinnej krwi Jezusa przyjmie na siebie otwarcie i w pełni cały lud wraz ze swym potomstwem $(27,25)^{20}$.

\section{Bibliografia}

Alon G., The Jews in their Land in the Talmudic Age (70-640 C.E), Jerusalem 1980.

Broer I., Redaktiongeschichtliche Aspekte von Mt 24,1-28, NT 35 (1993), s. 209-233.

Coggins R.J., Haggai, Zechariah, Malachi, Scheffield 1996.

Daube D., Judas, California Law Review 82 (1994), 95-108.

Davies W.D., Allison D.C., The Gospel according to Saint Matthew (CEC III), LondonNew York $2004^{3}$.

Guillet J., Jezus w wierze pierwszych uczniów, Kraków 2000.

Jocz J., Jesus and the Law, Judaica 26 (1970), s. 105-124.

Légasse S., Le refroidisment déamour avant la fin (Mt 24,12), SNTU.A 8 (1983), s. 91$-102$.

Luz U., Das Evangelium nach Matthäus (EKK IV), Neukirchen-Vluyn 2002.

19 Por. W.D. Davies, D.C. Allison, The Gospel, s. 568-570; U. Luz, Das Evangelium, s. 230-232.240; D.J. Moo, Tradition, s. 157-175; D. Senior, The Fate, s. 372-426; S. van Tilborg, $M t$ 27,3-10, s. 159-174.

20 Por. Z. Żywica, Kościół Jezusa, s. 292-295. 
Moo D.J., Tradition and Old Testament in Mt 27,3-10, in: R.T. France, R.T. France, D. Wenham (ed.), Gospel Perspectives III, Sheffield 1983, s. 157-175.

Moore J.F., Judaism in the First Centuries of the Christian Era. The Age of the Tannaim I-II, New York $1871^{2}$.

Neusner J., Das Pharisäische und Talmudische Judentum, TSAJ 4 (1984), s. 25-95.

Neusner J, Judentum in frühchristlicher Zeit, Stuttgart 1988.

Neusner J., The Formation of Rabbinic Judaism: Yavneh (Jamnia) from A.D. 70-100, ANRW 192 (1979), s. 3-42.

Neusner J., The Rabbinic Traditions about the Pharisees before 70, III, Leiden 1971.

Paciorek A., Ewangelia według świętego Mateusza 1-13. Wstęp - przekład z oryginału komentarz (NKB I.1), Częstochowa 2005.

Schürer E., Vermes G., The History of the Jewish People in the Age of Jesus Christ (175 B.C. - A.D. 135) I-III, Edinburg 1973-1987.

Senior D., The Fate of the Betrayer: A Redactional Study of Mt 27,3-10, EThL 48 (1972), s. 372-426.

Spicq C., L 'amour de charité se refroidera (Mt 24,12), in: L. Lucchesi, H.D. Saffrey, Mémorial A.J. Festugière, Genève 1984, s. 113-117.

Spitzer S., Modły Izraelitów na dni powszednie i święta, uroczystości i posty oraz obrządki i ceremonie religijne, Kraków 1926 (przedruk: Warszawa 1991).

Stemberger G., Die sogenannte „Synode von Jabne“ und das frühe Christentum, Kairos 19 (1977), s. 14-21.

Taylor J., „The Love of Many will Grow Cold”: Mt 24,9-13 and the Neronian Persecution, RB 96 (1989), s. 352-357.

Thompson W.G., A Historical Perspective in the Gospel of Matthew, JBL 93 (1974), s. $243-262$.

Tilborg van S., Mt 27,3-10: An Intertextual Reading, in: S. Draisma (ed.), Intertextuality in Biblical Writings, Kampten 1989, s. 159-174.

Zeitlin S., Beginnings of Christianity and Judaism, JQR 27 (1936/37), s. 385-398.

Zeitlin S., The Rise and Fall of the Judean State. A Political, Social and Religious History of the Second Commonwealth III (66-120), Philadelphia 1978.

Wehelan C.E., Suicide in the Ancient World: A Re-Examination of Mt 27,3-10, LTP 49 (1993), s. 505-522.

Żywica Z., Kościół Jezusa a judaizm i poganie według ewangelisty Mateusza. Teologia narratywna, Olsztyn 2006. 